EUROPA REGIONUM TOM XXIII ROK 2015

DOI: 10.18276/er.2015.23-01

GRZEGORZ GOŁEMBSKI

Uniwersytet Ekonomiczny w Poznaniu

\title{
Miejsce ekologii i ochrony środowiska w kreowaniu i promocji produktu turystycznego przez samorządy
}

\section{Wprowadzenie}

D odstawą rozważań jest szerokie ujęcie produktu turystycznego. Zawarte w nim są wszystkie dobra i usługi (wliczając w to walory naturalne i antropogeniczne obszaru), które zaspakajają potrzeby wynikające $z$ wyjazdu poza miejsce stałego zamieszkania. Produkt zawsze związany jest $\mathrm{z}$ określonym obszarem będącym miejscem zainteresowania turysty, chociaż można go także poszerzyć na wszystkie dobra i usługi kupowane w związku $\mathrm{z}$ wyjazdem $\mathrm{w}$ miejscu zamieszkania turysty i w drodze do miejsca przeznaczenia. Biorąc pod uwagę destynację turystyczną, produkt stanowi zespół świadczeń z podstawową ofertą walorów turystycznych, usług bytowych i handlowych: udogodnień o nierynkowym charakterze ochrony środowiska, bezpieczeństwa czy usług umożliwiających korzystanie z dóbr turystycznych (rekreacyjnych, sportowych, rozrywkowych, leczniczych itp.) (Gołembski red. 2009). Z punktu widzenia konsumenta produkt turystyczny obejmuje całość przeżyć i doświadczeń związanych z uprawianiem turystyki, które na obszarach turystycznych stanowią dwie grupy komponentów: środowiska i infrastruktury (Majewska 2012). Jedynie takie ujęcie zapewnia kompleksowe zagospodarowanie obszarów turystycznych ujmując także problemy ochrony środowiska.

Istnieje bowiem niebezpieczeństwo pojmowania produktu w zbyt wąski sposób (szlak, wydarzenie, obiekt itp.) (Kaczmarek, Stasiak, Włodarczyk 2005). Upraszcza to pojęcie produktu do jego rdzenia (a i to jest wysoce wątpliwe - jak 
można uznać za rdzeń produktu turystycznego pole golfowe czy bulwar nad Wartą). W sposób wypaczony określa prawdziwy rozwój usług turystycznych sprawiając absolutnie mylne wrażenie, że produkty są gotowe, czekają na turystów i trzeba je jedynie wypromować. Koncentruje się na jakimś punkcie czy miejscu, a nie na interesach społeczności lokalnej, gospodarki czy ochronie środowiska będących podstawą rozwoju zrównoważonego.

W dobie globalnej konkurencji między regionami turystycznymi poszukuje się takich propozycji i ofert, które odpowiadałyby na nowe trendy w rozwoju popytu turystycznego. Owe trendy stymulują do poszukiwania produktów oferowanych przez miasta (jako centra kultury, rozrywki, zakupów i biznesu), a także takich produktów, które są konsekwencją wzrostu świadomości związanej z ekologią i ochroną środowiska. Konsekwencją tej świadomości jest wzrost atrakcyjności „dziewiczych” chronionych obszarów i popytu na ekoturystykę. Należy podkreślić, że poziom równowagi między rozwojem turystyki a priorytetami dotyczącymi ochrony środowiska jest zmienny w zależności od obszaru. Dla niektórych siedlisk sens ma tylko niewielkie zaangażowanie turystyki, dla innych będzie ona kluczowym czynnikiem rozwoju (Gołembski, Nawrot 2002).

Powstają pytania: kto i jak ma kształtować taki złożony produkt turystyczny na obszarach chronionych - produkt oferowany przez przedsiębiorców, samorządy i społeczność lokalną? A także jak kształtować produkt w sytuacji złożonych problemów ochrony środowiska oraz zróżnicowania instytucjonalnego dotyczącego tej ochrony? Odpowiedź na te pytania nie jest możliwa bez uwzględnienia władz samorządowych na różnych szczeblach. Dlatego celem referatu jest określenie zadań samorządu w kreacji produktu turystycznego na obszarach chronionych.

\section{Uwarunkowania}

Podstawowym uwarunkowaniem w zakresie kształtowania produktu jest turystyka zrównoważona rozumiana jako kompromis pomiędzy interesami kreatorów usług turystycznych (w tym ludności miejscowej), ludności miejscowej ogółem (a wiec także tych, którzy nie zarabiają bezpośrednio na obsłudze turystów), samych turystów, jak i koniecznością ochrony środowiska naturalnego. Innymi słowy jest to każda forma rozwoju turystycznego, zarządzania i aktywności turystycznej, która podtrzymuje ekologiczną, społeczną i ekonomiczną integralność 
terenów, a także zachowuje w niezmienionym stanie zasoby naturalne i kulturowe tych obszarów (Niezgoda 2006). Jednym z celów tej turystyki jest integracja turystów ze społecznością lokalną. Podkreśla się wręcz, że turystyka na obszarach przyrodniczo cennych musi współuczestniczyć w rozwoju lokalnym poprzez aktywizację ludności miejscowej (Miedzińska 2008). Musi być osiagnięty kompromis, bowiem konieczność ochrony przyrody przyczynia się do ograniczania ruchu, co może spowodować zmniejszenie wpływów z tytułu obsługi turystów i nie jest bez znaczenia szczególnie $\mathrm{w}$ dobie kryzysu. $Z$ drugiej strony od jakości ekosystemów uzależniony jest dalszy rozwój turystyki. Przyjmuje się, że im większa wartość przyrody, tym mniejsze powinno być użytkowanie turystyczne (StaniewskaZątek 2007). Osiaganie tego kompromisu jest zadaniem długotrwałym i musi być wsparte zarówno intensywną edukacją proekologiczną i działaniami natury prawnej nawet na szczeblu międzynarodowym. Ich efektem jest zapobieganie przekraczania pojemności ekologicznej, która określa granicę turystycznego otwarcia na inwestycje turystyczne i granice, do której może być przyjmowany ruch turystyczny bez groźby utraty przez dany teren atrakcyjności turystycznej (Kachniewska, Nawrocka, Niezgoda, Pawlicz 2012). Uważa się, że rozwój turystyki na obszarach przyrodniczo cennych nie nastąpi, jeśli osoby zarządzające obszarami o wartości turystycznej, akcjonariusze i sami turyści nie będą postępować odpowiedzialnie, mając na uwadze ochronę środowiska, gospodarkę i etykę (Hakon, Huijbens 2011). Stąd niezbędna jest edukacja proekologiczna.

Edukacja proekologiczna polega na propagowaniu wiedzy ekologicznej zarówno wśród turystów, jak i oferujących usługi (mniejsze zużycie dóbr, preferowanie produktów mniej uciążliwych dla środowiska, wydłużenie okresów ich użytkowania). Przykładem takich działań jest projekt Instytutu na rzecz Ekorozwoju „Prawidłowe wykorzystanie zasobów przyrodniczych obszarów Natura 2000 w turystyce wiejskiej na poziomie lokalnym" (www.ine-isd.org.pl).

Działania natury prawnej na szczeblu międzynarodowym dotyczą przede wszystkim programu Natura 2000. Przejawem takich działań jest ogłoszenie przez Komisję Europejską 3.05.2011 nowej „Unijnej strategii ochrony różnorodności biologicznej”, która wyznacza kierunki działania na najbliższe 10 lat oraz dłużej, aż do $2050 \mathrm{roku}$ (www.europa.eu/legislation/maritime). Strategia ta została przyjęta przez Radę Unii Europejskiej (ds. ochrony środowiska) w czerwcu 2011 roku. $\mathrm{Na}$ tej podstawie powstały w Polsce plany zadań ochronnych dla obszarów Natura 2000 sporządzone przez Generalną Dyrekcję Ochrony Środowiska. 
Zostanie to omówione podczas analizy zadań samorządów w kształtowaniu produktu turystycznego.

\section{Studium przypadku - Międzynarodowa droga wodna E 70}

To niezwykle ciekawy, europejski projekt łączący drogą wodną Antwerpię z Kaliningradem. Bardzo długi odcinek tej drogi przebiega przez terytorium Polski - od ujścia Warty do Odry aż do Zalewu Wiślanego. Brany przez nas pod uwagę odcinek dotyczy województwa lubuskiego: od Kostrzyna nad Odrą do Drezdenka. Jest to odcinek o długości $123 \mathrm{~km}$ w tym 70-kilometrowy odcinek Warty, 47-kilometrowy odcinek Noteci i 6-kilometrowy odcinek Odry. Wzdłuż szlaku znajdują się takie ciekawe miejscowości jak: Kostrzyn nad Odrą z tradycją walk podczas II wojny światowej i przystankiem Woodstock z teraźniejszości czy Santok - brama Słowiańszczyzny i miejsce ujścia Noteci do Warty. Utworzenie tej drogi wodnej jest ogromną szansą dla lokalnego biznesu i mieszkańców na rozwój turystyki międzynarodowej, przypływ znacznych środków finansowych od inwestorów i turystów i pojawienie się silnych efektów mnożnikowych. Jednakże cały ten obszar objęty jest programem Natura 2000. Stanowi to siłę przyciagania turystów. Jak wynika z badań, dla $64 \%$ turystów wypoczynek $\mathrm{w}$ miejscach o szczególnych walorach przyrodniczych ma duże znaczenie, w przypadku połowy badanych istnienie obszarów Natura 2000 było podstawą decyzji o spędzeniu tam urlopu (Kamieniecka 2012). Jednocześnie ścisła ochrona przyrody jest niewątpliwie utrudnieniem w tworzeniu i realizacji strategii rozwoju produktu turystycznego na tym obszarze.

Występują tu takie obszary Natura 2000 jak:

1. Park Narodowy „Ujście Warty” o powierzchni 33297 ha - obszar zarówno siedliskowy, jak i legowy dla licznych gatunków ptactwa.

2. Obszar o nazwie „Ostoja Witnicko - Dębiańska” o powierzchni aż 46993 ha będący ostoją lęgową dla licznych gatunków ptactwa.

3. Dolina dolnej Noteci o powierzchni 20154 ha - także ostoja lęgowa ptactwa.

4. Ujście Noteci o powierzchni 3995 ha jako obszar siedliskowy (http://natura2000gdos.gov.pl/natura2000).

W sumie więc obszar kreacji nowego produktu turystycznego to obszar chroniony o powierzchni dochodzącej do 105000 ha. Jest to omalże $25 \%$ powierzchni województwa lubuskiego nadzorowane przez Regionalną Dyrekcję 
Ochrony Środowiska w Gorzowie. Warto wspomnieć, że chroniąc cenne przyrodniczo obszary, człowiek w sposób niezamierzony tworzy nowe, bardzo atrakcyjne przyrodniczo przestrzenie turystyczne. Dzieje się tak dlatego, że fakt objęcia ochroną prawną jakiegoś obszaru przez utworzenie np. parku narodowego lub krajobrazowego natychmiast wzmaga zainteresowanie tą przestrzenią i powoduje często wielokrotnie zwiększony ruch turystyczny (Liszewski 2006). Należy jednak zauważyć, że rozwój funkcji turystycznej nie odbywa się w sprzeczności z funkcją ochronną. Turystyka jest bowiem jednym z najbardziej pożądanych kierunków rozwoju gospodarczego obszarów chronionych. Nawet w odniesieniu do parków narodowych jednym z założeń funkcjonowania tych obszarów jest rozwój funkcji turystycznej w ich obrębie (Pawlusiński 2005).

\section{Zadania samorządu w kształtowaniu produktu turystycznego}

Jak już wspomniano, produkt turystyczny tworzony jest lub współtworzony przez podmioty gospodarcze, samorządy, instytucje rządowe i ich oddziały regionalne oraz ludność miejscową. Samorządy odgrywają najistotniejszą rolę w fazie kreacji produktu turystycznego oraz jego dystrybucji i promocji. Działania te są bezpośrednio związane z rozwojem turystyki (dotyczą charakterystycznych rodzajów działalności turystycznej - zaplecza noclegowego, gastronomicznego, dróg dojazdowych, informacji, usług rekreacyjnych, parkingów, renowacji obiektów zabytkowych, przewodnictwa itp.). Mają one też charakter pośredni, ale stanowią niezbędne uzupełnienie produktu. Zaliczyć można do nich takie działania, jak rozwój infrastruktury technicznej, ochronę środowiska naturalnego, analizę stosunków ludnościowych, zapotrzebowanie na pracę, możliwości inwestycyjne czy rozwój komunikacji. Działania te przenikają się wzajemnie. Władze samorządowe spełniają też kluczową rolę w prowadzeniu polityki przestrzennej na terenie gmin w regionach turystycznych (Nawrot, Zmyślony 2009).

W pierwszej fazie budowy produktu turystycznego niezbędne jest opracowanie rdzenia produktu na wybranym obszarze, a w dalszej kolejności propozycje budowy infrastruktury dla wybranego rodzaju turystyki, a także zaplecza noclegowego i gastronomicznego. Zadania te należą do samorządów wojewódzkich i lokalnych jako partnerów dla przyszłych inwestorów.

Rdzeniem produktu na wybranym przez nas obszarze jest rozwój turystyki wodnej we wszelkich jej przejawach. Udział samorządów w tworzeniu przesłanek 
do rozwoju inwestycji zależy od określenia lokalizacji ogólnej i szczegółowej przyszłych inwestycji. Na etapie lokalizacji ogólnej decyzje podejmowane są przez samorządy wojewódzkie i powiatowe, na etapie lokalizacji szczegółowej przez gminne. Lokalizacja ta dotyczyć może zarówno obszarów objętych ochroną środowiska, jak i ich otuliny.

Analiza czynników lokalizacji ogólnej musi dać odpowiedź na pytanie, czy na danym obszarze występują wystarczające przesłanki ku temu, by inwestycja turystyczna mogła zaistnieć. Jednym z najistotniejszych czynników są walory turystyczne obszarów, a także ich ochrona. Poza tym liczy się położenie obszarów względem rynków zbytu, jego dostępność komunikacyjna, analiza zasobów siły roboczej, profil społeczno-ekonomiczny (zdolność do absorpcji kapitału i inwestycji - plany zagospodarowania przestrzennego), poziom cen ziemi czy dynamika rozwoju nowoczesnych usług (banki, ubezpieczenia itp.).

$\mathrm{Na}$ tym etapie kwestie ochrony środowiska szczególnie na obszarach Natura 2000 muszą odgrywać istotną rolę. W tej materii występuje konieczność współdziałania wielu niezależnych od siebie instytucji.

Egzekwowaniem przepisów dotyczących ochrony środowiska zagrożonego szybko postępującymi procesami inwestycyjnymi czy rozwojem infrastruktury komunikacyjnej zajmują się regionalne dyrekcje ochrony środowiska. Odpowiadają one za realizację polityki ochrony środowiska w zakresie zarządzania ochroną przyrody, w tym Natura 2000, kontroli procesu inwestycyjnego poprzez przeprowadzenie ocen oddziaływania na środowisko przedsięwzięć oraz udział w strategicznych ocenach. Realizują także zadania dotyczące zapobiegania i naprawy szkód w środowisku. Regionalne dyrekcje ochrony środowiska sa częścią pionu administracyjnego niepodlegającego jurysdykcji samorządów. Na czele stoi Minister ds. Ochrony Środowiska. Dalsze szczeble tworzą generalny dyrektor ochrony środowiska oraz na najniższym szczeblu Państwowa Inspekcja Ochrony Środowiska. Trzeba jednak podkreślić, że w procesie ochrony środowiska bierze udział wiele innych instytucji związanych i niezwiązanych z samorządami.

Efektem oddziaływania na środowisko podejmowanych procesów inwestycyjnych zajmują się też Wojewódzkie Inspektoraty Ochrony Środowiska. Ich głównym zadaniem jest monitoring środowiska umożliwiający szybkie wychwycenie wszelkich negatywnych skutków zarówno działalności inwestycyjnej jak i eksploatacji obiektów czy urządzeń służących turystom. 
Kontrola wpływu podejmowanych działań inwestycyjnych na środowisko nie zamyka problemu. Ochrona środowiska wymaga też dodatkowych inwestycji zabezpieczających środowisko przed działaniem czynników zewnętrznych. Finansowaniem tej działalności zajmuje się Narodowy Fundusz Ochrony Środowiska i Gospodarki Wodnej, któremu podlega 16 wojewódzkich funduszy. Wspierają one na poziomie regionalnym finansowanie wspomnianych wyżej inwestycji (w latach 1989-2013 wydatki funduszy na ten cel przekroczyły poziom 33 mld złotych, co stanowiło około $28 \%$ całej puli wydatków na ochronę środowiska) (www.nfosigw.gov.pl).

Tak skomplikowana struktura niewątpliwie ogranicza kompetencje i możliwości władz samorządowych na szczeblu województw w zakresie aktywnego kształtowania produktu turystycznego w drodze realizacji inwestycji. Z drugiej strony powołanie niezależnych od samorządów instytucji sprzyja dodatkowej kontroli i zwiększa efektywność działań ochronnych szczególnie wtedy, kiedy w grę wchodzą obszary chronione.

Można stwierdzić, że w tej sytuacji rola władz samorządowych na szczeblu województw sprowadza się do promowania działań proekologicznych. Takie bowiem działania przypisane są Departamentom Środowiska przy Urzędach Wojewódzkich.

Z analizy czynników lokalizacji ogólnej inwestycji wynikają pytania pod adresem władz regionalnych. Odpowiedź na te pytania ma kluczowe znaczenie dla dalszego rozwoju inwestycji i dla rozwoju krajowej i zagranicznej turystyki przyjazdowej. Są one następujące:

- Czy proponowane inwestycje nie mają negatywnego wpływu na środowisko naturalne?

- Czy tworzone są projekty rozwoju infrastruktury środowiska naturalnego, a także rozwoju gospodarki lokalnej mogące być podstawą ubiegania się o fundusze unijne, a których realizacja spowoduje większą siłę przyciagania kapitału? Czy istnieje możliwość finansowania tych projektów poprzez wojewódzkie fundusze ochrony środowiska?

- Czy walory turystyczne terenu są dostatecznie wyeksponowane w planach zagospodarowania przestrzennego?

- Jakie są poczynania władz regionalnych, które stymulują poprawę dostępności komunikacyjnej obszaru i czy zgodne są one z koniecznością ochrony środowiska? 
- Czy tworzy się system szkoleń umożliwiających pracę w sektorze turystyki bądź tworzenie własnego biznesu?

Z powyższych rozważań wynika, że zadaniem samorządu regionalnego (szczebel wojewódzki) jest opracowanie rdzenia produktu na wybranym obszarze. Jak już wspomniano, rdzeniem tym dla wybranego obszaru jest rozwój turystyki wodnej $\mathrm{w}$ oparciu o zaprojektowaną specjalistyczną infrastrukturę turystyczna. Władze samorządowe mogą to zadanie zlecić wyspecjalizowanym instytucjom (np. Regionalne Organizacje Turystyczne). Opracowanie to powinno być poprzedzone analizą rynku (szczególnie badaniem obecnego popytu i trendów jego rozwoju). Budowa infrastruktury turystycznej poprzedzona być musi analizą czynników lokalizacji ogólnej. Jednakże ostateczna decyzja dotycząca inwestycji na obszarach podlegających ochronie środowiska uzależniona jest od decyzji merytorycznych i finansowych podejmowanych przez instytucje niepodlegające jurysdykcji samorządów. Niezbędna jest więc współpraca, a w razie konfliktu interesów zastrzeżone są działania, których efektem jest niedopuszczenie do degradacji środowiska. Można to przedstawić na poniższym rysunku:

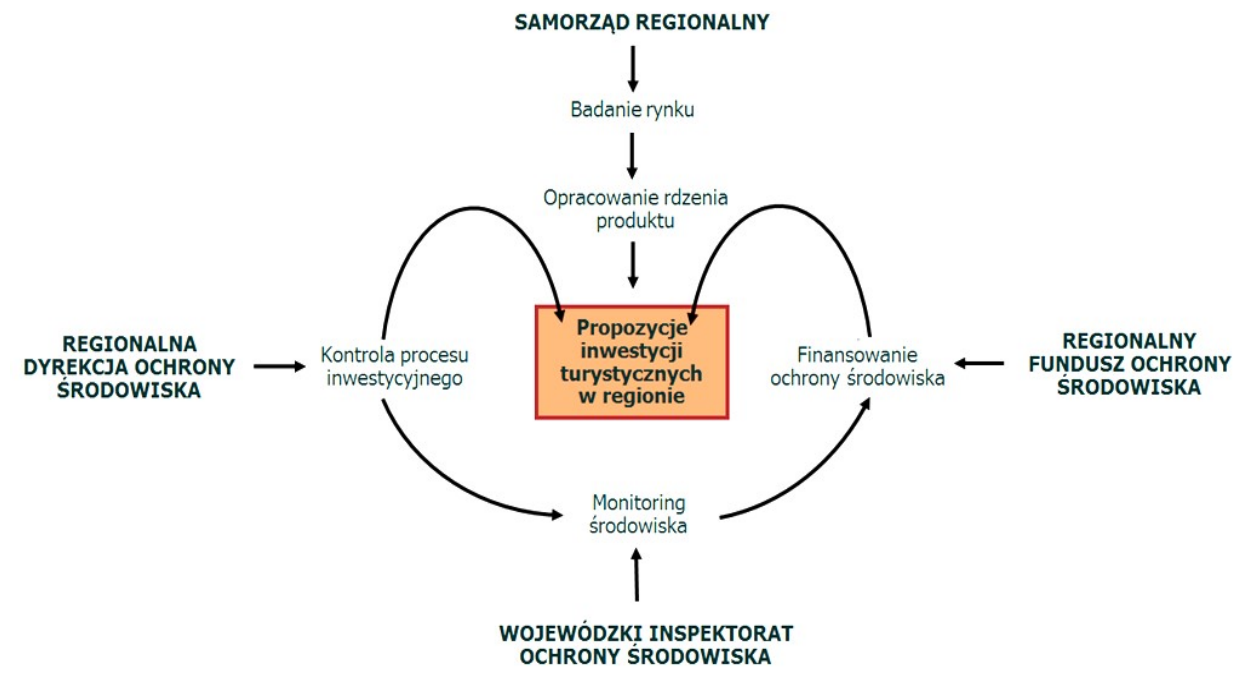

Rysunek 1. Proces podejmowania decyzji inwestycyjnych $w$ infrastrukturę turystyczną na obszarach chronionych

Źródło: opracowanie własne.

Stwierdzenie zasadniczych przesłanek do realizacji inwestycji na obszarze, na którym chcemy kształtować produkt turystyczny, a także potwierdzenie, że 
inwestycja nie wpłynie na pogorszenie stanu środowiska naturalnego, jest warunkiem dokonania analizy lokalizacji szczegółowej. Ta z kolei ma miejsce na poziomie gminnym.

Konkretne usytuowanie obiektu rozpatruje się przez pryzmat następujących okoliczności: układu sieci dróg dojazdowych (odległości od węzłów komunikacyjnych - dworzec, lotnisko), infrastruktury technicznej (sieć kanalizacyjna, wodna i elektryczna), stosunków gruntowych o charakterze prawnym i techniczno-technologicznym a także charakterystyki bezpośredniego otoczenia w sensie bezkolizyjności wybranego miejsca. Szczególną wagę należy przypisać infrastrukturze technicznej, bowiem uzbrojenie terenu w sposób bezpośredni przyczynia się do ochrony środowiska. Duże znaczenie przypisać należy działaniom samorządu gminnego w zakresie gospodarki komunalnej. Działania te mają ścisły związek z ochroną środowiska. Utylizacja odpadów, oczyszczalnie ścieków, oświetlenie ulic, tworzenie ładu przestrzennego to podstawa utrzymania środowiska w stanie nieskażonym bądź hamowania procesów jego degradacji.

Realizacja tych podstawowych czynności pozwoli na prowadzenie działań zmierzających bezpośrednio do dostosowania produktu turystycznego do potrzeb turystów. Myślimy tu o oznakowaniu, budowie szlaków, informacji turystycznej czy budowie parkingów.

Inwestycje $\mathrm{w}$ infrastrukturę turystyczną i paraturystyczną nie są jedynym zadaniem władz samorządowych w procesie kreacji nowych produktów turystycznych. Jednakże na obszarach chronionych proces podejmowania decyzji inwestycyjnych musi być wyodrębniony, bowiem zagrożenia dla środowiska naturalnego, jakie mogą wyniknąć wskutek realizacji decyzji inwestycyjnych, mogą doprowadzić do załamania planów rozwoju turystyki na badanym obszarze. Zatem pozytywna ocena projektów inwestycyjnych tak pod względem ich lokalizacji ogólnej, jak i braku kolizji z ochroną środowiska może dopiero uruchomić drugi etap związany z kreacją produktu turystycznego. Na tym etapie proces inwestycyjny (lokalizacja szczegółowa obiektów) wchodzi w fazę realizacji i staje się przedmiotem zainteresowania władz na poziomie gminnym.

Budowa infrastruktury turystycznej łączy się z szeregiem innych działań będących w gestii zarówno szczebla regionalnego, jak i lokalnego. Odzwierciedlono to na poniższym rysunku. 


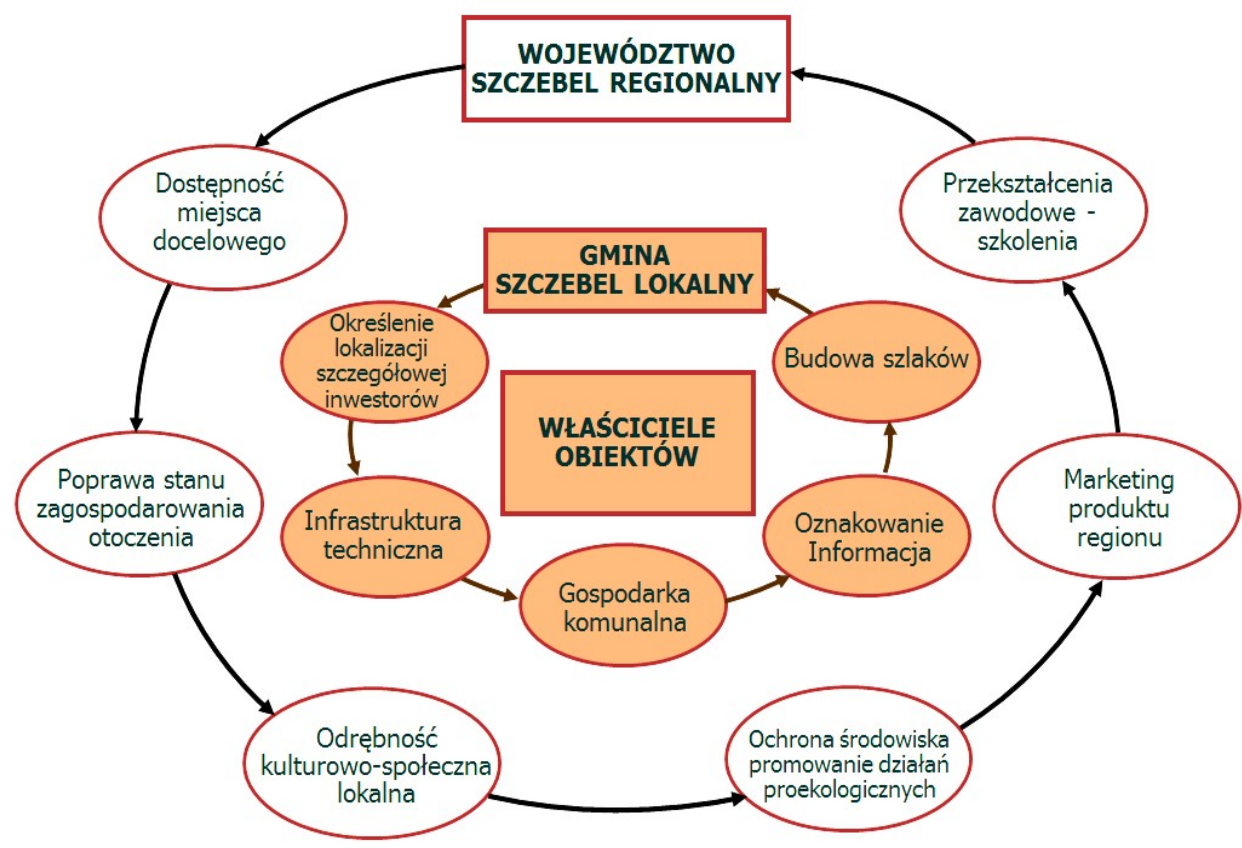

Rysunek 2. Rola sektora publicznego w tworzeniu strategii produktu turystycznego

Źródło: opracowanie własne.

Na szczeblu regionalnym zadaniem samorządów jest poprawa dostępności miejsca docelowego oraz poprawa stanu zagospodarowania otoczenia. Nie ma to bezpośredniego związku z rozwojem turystyki - jednakże poprawa estetyki już istniejących zabudowań ma związek z pięknem krajobrazu i jest elementem kształtowania środowiska. Niezbędne jest też kultywowanie i pogłębianie odrębności kulturowej społeczności lokalnej, która jest istotnym składnikiem produktu turystycznego. Promowanie działań proekologicznych zapobiegających degradacji środowiska $\mathrm{w}$ przyszłości jest wpisane $\mathrm{w}$ zadania samorządu na szczeblu regionalnym. Kolejne zadania dotyczą już tzw. inwestycji miękkich, takich jak marketing produktu regionu oraz przekształcenia zawodowe i szkolenia. Program szkoleń dla podmiotów działających na rynku turystycznym ma na celu pobudzanie przedsiębiorczości i innowacyjności (Zmyślony 2008). Z kolei działania marketingowe dotyczyć powinny całościowego produktu turystycznego, a nie tylko rdzenia produktu w postaci szlaku wodnego czy uruchomienia podstawowej infrastruktury. Promowanie produktu nie w pełni dostosowanego do potrzeb turystów może spowodować zaniżenie jego jakości w odczuciu turystów. 
Rola władz samorządowych zarówno na szczeblu regionalnym, jak i lokalnym wynika z zadań, jakie zostały przed nimi postawione w ustawie o samorządzie terytorialnym. Samorządy jako gospodarze swojego terenu tworzą strategie rozwoju turystyki, dzięki której mogą mieć długoletnią wizję dotyczącą tworzenia produktu turystycznego. Częstokroć są one też dysponentami środków finansowych zarówno własnych, jak i pochodzących z Unii Europejskiej. Z tych racji są one predystynowane do roli przywódcy i koordynatora działań w tak skomplikowanej materii, jaka jest kreacja produktu turystycznego. Nie oznacza to jednak, że samorządy muszą te zadania wykonywać samodzielnie i własnymi siłami. W większości przypadków delegowanie własnych uprawnień innym instytucjom jest bardziej efektywne. Główne korzyści z kooperacji wynikają bowiem z dostępu do dodatkowych źródeł zasobów będących w posiadaniu partnerów (zasoby materialne, ale także wiedza czy kompetencje) (Czernek 2012). Kooperacja umożliwia przy tym utożsamianie się ze strategią rozwoju turystyki innym podmiotom (marketing i promocja produktu). Rozwiązaniem jest tworzenie mieszanych spółek publiczno-prywatnych, których celem byłoby kreowanie i zarządzanie całym produktem turystycznym tworzącym dany szlak. Byłby to swoisty przywódca (pod protektoratem władz wojewódzkich) koordynujący i inspirujący działania inwestorów oraz drobnego biznesu, a także władz lokalnych (gminy). Podstawą działania owej spółki winny być pieniądze uzyskane ze środków unijnych na podstawie własnych wniosków, a także wniosków władz samorządowych. Podstawową rzeczą jest także przyciaganie inwestorów poprzez tworzenie dogodnych lokalizacji, a przede wszystkim wydawanie pozwoleń środowiskowych. Zadaniem inwestorów jest głównie budowa marin, stanic i przystani zarówno dla statków, jak i jachtów i łodzi (sklepy żeglarskie, spożywcze, stacje benzynowe), a także budowa zaplecza noclegowego i gastronomicznego.

Z kolei projekty będące podstawą uzyskania funduszy unijnych powinny podkreślać przedsiębiorczość i innowacyjność planowanych poczynań. Przykładem takich projektów jest budowa szlaków wodnych, a także rowerowych i pieszych umożliwiających pełną penetrację terenów nadrzecznych, przywracanie autentyczności obszarów wiejskich, rekonstrukcje staropolskich pieców kuchennych i realizację staropolskich receptur czy uruchamianie produkcji pamiątek. Nie można też zapominać o parkingach i infrastrukturze usługowej.

Jak już wspomniano, marketing i promocja produktu dotyczyć powinna oferty kompleksowej zaspakajającej wszystkie potrzeby turysty. Działania 
te powinny być realizowane na trzech szczeblach. Rolę koordynatora działań marketingowych dotyczących propagowania proponowanego produktu turystycznego pełnić powinna odpowiednia komórka samorządu wojewódzkiego lub związku międzygminnego odpowiedzialna za marketing. Działania te mogą być tak że delegowane do organizacji reprezentujących biznes lokalny i ludność miejscową (ROT-y czy stowarzyszenia). Musiałyby one jednak prowadzić promocje produktu zlokalizowanego na obszarze województwa.

W samorządzie lokalnym tego typu komórka powinna prowadzić działania wytyczone przez koordynujący organ, a także bezpośrednio odpowiadać za prowadzenie strategii marketingu dotyczącej fragmentu produktu znajdującego się na obszarze gminy. Wreszcie ostatnim ogniwem w prowadzeniu działań marketingowych są właściciele i bezpośredni zarządzający konkretnymi obiektami. Prowadząc samodzielne działania mogą oni jednak decydować się na dotarcie do klienta poprzez internetowe przekazy dotyczące promocji całego obszaru.

\section{Podsumowanie}

Z przedstawionych rozważań wynika, że na obszarach chronionych, szczególnie objętych programem Natura 2000, idea turystyki zrównoważonej jest nieadekwatna do rzeczywistości. Ochrona przyrody ma bowiem bezwzględny priorytet nad interesami oferujących usługi i ludności miejscowej liczącej na rozwój regionu i uruchomienie efektów mnożnikowych. W tej sytuacji, jeżeli zamierzamy wykreować produkt turystyczny na obszarach chronionych (np. takich, przez które prowadzi międzynarodowa droga wodna), należy zadać sobie pytanie o możliwość tworzenia tego produktu w ogóle i o czynniki ograniczające ten rozwój. Odpowiedź na tak sformułowane pytanie wymaga uzgodnień z niezależnymi od samorządów instytucjami powołanymi do ochrony środowiska, jego monitoringu i finansowania działań wzmacniających jego ochronę już na etapie badań rynku, w wyniku których możliwe byłoby opracowanie rdzenia produktu i produktu rzeczywistego na obszarach chronionych. Pozytywna odpowiedź na tak postawione pytanie umożliwi konsekwentną realizację wizji działań proekologicznych w tworzeniu i sposobach oferowania podstawowych usług turystycznych. Ta realizacja działań proekologicznych związanych z kreacją produktu turystycznego możliwa jest tylko wówczas, kiedy samorządy będące gospodarzami obszarów, na których ma rozwijać się ruch turystyczny, będą dysponowały swoistą „mapą drogową” polegająca na wiedzy, jakie działania i w ja- 
kiej kolejności muszą zostać podjęte na różnych szczeblach, aby wykreować kompleksowy produkt turystyczny. Nie oznacza to, że samorządy same muszą podejmować działania zmierzające do kreacji produktu. Możliwe jest cedowanie swoich uprawnień na inne podmioty (spółki non-profit, stowarzyszenia itp.), dzięki którym do działań związanych z kreacją produktu mogliby się włączyć właściciele obiektów i ludność miejscowa. Jednakże nikt bardziej, jak samorządy regionalne czy lokalne posiadające dzięki strategii wizję turystycznego rozwoju obszarów chronionych nie jest bardziej predystynowany do partnerstwa z niezależnymi od niego instytucjami odpowiadającymi za ochronę środowiska, jego monitoring i finansowanie. Zadaniem samorządów winno być wypośrodkowanie (zgodnie z ideą rozwoju zrównoważonego) interesów ludności oraz ochrony środowiska i uruchomienie procesów mnożnikowych przy pełnym wspomaganiu działań proekologicznych. Umożliwienie ludności miejscowej świadczenia usług turystycznych (wynajem pokoi, serwowanie posiłków na bazie kuchni domowej) zwiększyłoby niezmiernie jej aktywność i usposobiłoby pozytywnie do rozwoju turystyki (Gołembski, Nawrot 2002). Ma to szczególne znaczenie w dobie kryzysu, którego konsekwencją jest ubożenie ludności. W tych warunkach działania o charakterze restrykcyjnym mogą prowadzić w konsekwencji do naruszeń prawa.

\section{Bibliografia}

Czernek K., Uwarunkowania wspótpracy na rzecz rozwoju turystyki w regionie, Proksenia, Kraków 2012.

Gołembski G., Nawrot Ł., Rozwój turystyki zrównoważonej w parkach krajobrazowych nowe trendy $w$ Unii Europejskiej, w: Zarzqdzanie parkiem krajobrazowym $w$ warunkach zrównoważonego rozwoju, AE, Poznań 2002.

Gołembski G. (red.), Kompendium wiedzy o turystyce, Wydawnictwo naukowe PWN, Warszawa 2009.

Huijbens E.H., Turystyka w obszarach przyrodniczo cennych, w: A. Dłużniewska (red.), Nowe wyzwania edukacji turystycznej, Warszawa 2011.

Kachniewska M., Nawrocka E., Niezgoda A., Pawlicz A., Rynek turystyczny - ekonomiczne zagadnienia turystyki, Oficyna a Wolters Kluwer business, Warszawa, 2012.

Kaczmarek J., Stasiak., Włodarczyk B., Produkt turystyczny, Łódź 2005.

Kamieniecka J., Świadomość ekologiczna turystów, Instytut na rzecz ekorozwoju, Warszawa 2012.

Liszewski S., Nowe przestrzenie turystyczne i rekreacyjne $w$ Polsce i ich rola $w$ rozwoju kraju i regionu, w: G. Gołembski (red.), Turystyka w ujęciu podmiotowym i przestrzennym, AE, Poznań 2006. 
Majewska J., Rola samorzq̨du terytorialnego w ksztattowaniu funkcji turystycznej gminy, UEP, Poznań 2012.

Miedzińska J., Turystyka przyrodnicza - podstawy teoretyczne i determinanty rozwoju, Wydawnictwa PWSZ, Sulechów 2008.

Nawrot Ł., Zmyślony P., Międzynarodowa konkurencyjność regionu turystycznego, Proksenia, Kraków 2009.

Niezgoda A., Obszar recepcji turystycznej w warunkach zrównoważonego rozwoju, AE, Poznań 2006.

Pawlusiński R., Samorzad lokalny a rozwój turystyki, UJ, Kraków 2005.

Staniewska-Zątek W., Turystyka a przyroda i jej ochrona, Bogucki Wydawnictwo Naukowe, Poznań 2007.

Zmyślony P., Partnerstwo i przywództwo w regionie turystycznym, AE, Poznań 2008.

Strony internetowe:

www.ine-isd.org.pl

www.europa.eu/legislation/maritime

http://natura2000gdos.gov.pl/natura2000/

www.nfosigw.gov.pl

\section{The place of ecology and protection of the environment in the creation and promotion of a tourism product by local governments}

\section{Summary}

The aim of this work is to provide an answer to the question of who and how should develop a tourism product in protected areas. The paper explores the issue of developing a tourism product in the circumstances of complex problems of environmental protection and the diversity of institutional involvement in this protection. In other words, the aim is to describe the role of local government in the creation of a tourism product in a protected area.

The issue is discussed using the example of the E70 international inland waterway located within the boundaries of the Nature 2000 protected areas. Described are the ways of cooperation between local government and other institutional bodies responsible for preparing and issuing investments decisions leading to the creation of a tourism product in protected areas. The role of regional and local governments in developing a strategy for a tourism product is also discussed. 